\title{
Amniyosentez Öncesi Anksiyete Ve Depresyon Risk Düzeyi
}

\author{
Risk Level of Anxiety and Depression Before Amniocentesis
}

\author{
Seda Kırcı ERCAN ${ }^{1}$, Fedi ERCAN ${ }^{2}$, İbrahim EREN ${ }^{1}$, Hüseyin GÖRKEMLİ ${ }^{2}$, Ali ACAR ${ }^{2}$
}

1. Sağlık Bilimleri Üniversitesi, Eğitim ve Araştırma Hastanesi, Beyhekim Psikiyatri Kliniği, Konya, Türkiye

2. Necmettin Erbakan Üniversitesi, Meram Tıp Fak., Kadın Hast. ve Doğum Anabilim Dalı, Perinatoloji Bilim Dalı, Konya, Türkiye

\section{ÖZET}

Amaç: Amniyosentez yapilacak gebelerde anksiyete ve depresyon risk düzeylerini belirlemek.

Gerecler ve Yöntem: Çalıșma Nisan 2016 - Aralık 2016 tarihleri arasinda Necmettin Erbakan Üniversitesi, Meram Tip Fakültesi Hastanesi, Kadın Hastalıklarl ve Doğum Anabilim Dalı, Perinatoloji Ünitesinde amniyosentez yaplan toplam 109 gebe üzerinde yapılmıştır. İşlemden bir gün önce hastalara sosyodemografik veri formu ve Hastane Anksiyete Depresyon Ölçeği (HADÖ) formu doldurulmuştur.

Bulgular: Amniyosentez öncesi gebelerin anksiyete ölçeği (HA$D \ddot{O}$-A) ortalaması $11.18 \pm 2.36$ (aralık: 2-20) olarak bulunmuștur. Kesme noktası 10 olarak alındığında gebelerin $\% 72.5$ ' $i$ anksiyete yönünden risk altında oldukları saptanmıştır. Depresyon ölçeği (HADÖ-D) ortalaması ise $7.75 \pm 2.19$ (aralık: 2-19) olarak bulunmuştur. Kesme noktası 7 olarak alındığında gebelerin \%74.2 'si depresyon yönünden risk altında olduklart saptanmiştır.

Sonuç: Bu çalışmada amniyosentez öncesi gebelerin anksiyete ve depresyon düzeylerinin anlaml şekilde yüksek olduğu görülmüşürr. Amniyosentez yapılacak kadınların psikiyatrik desteğe ihtiyacr olabilir.

Anahtar Kelimeler: amniyosentez, anksiyete, depresyon

\section{ABSTRACT}

Objective: To detect the anxiety and depression risk levels of pregnant women's before the amniocentesis.

Material and Methods: This study was applied to 109 pregnant women before amniocentesis between April 2016 - December 2016 in the Necmettin Erbakan University, Meram School of Medicine Hospital, Department of Obstetrics and Gynecology, Division of Perinatology. One day before the procedure, sociodemographic data form and The Hospital Anxiety and Depression Scale (HAD) form were applied to pregnant women.

Results: The mean score of anxiety scale (HAD-A) was found $11.18 \pm 2.36$ (range: $2-20$ ) before the amniocentesis in pregnant women. Taking 10 as cutting point, $72.5 \%$ of them were found to be at risk in terms of anxiety. Depression scale (HAD-D) mean score was found $7.75 \pm 2.19$ (range: 2-19). Taking 7 as cutting point, $74.2 \%$ of pregnant women were found to be at risk in terms of depression.

Conclusion: At this study, anxiety and depression were determinated in the majority of pregnant women before amniocentesis. Pregnant women who are to undergo amniocentesis may need psychiatric support.

Keywords: amniocentesis, anxiety, depression

\section{İletişim Bilgileri}

Sorumlu Yazar: Fedi ERCAN

Yazışma Adresi: Necmettin Erbakan Üniversitesi, Meram Tıp Fakültesi, Kadın Hast. ve Doğum/Perinatoloji, Konya, Türkiye E-posta: fediercan@gmail.com

Tel: +90 (332) 2236000

Makale Geliş Tarihi: 22.11.2017

Makale Kabul Tarihi: 26.11.2017

DOI: http://dx.doi.org/10.16948/zktipb.357017

\section{GíRIŞ}

Gebelik bir kadının hayatındaki en sikıntılı ve stresli dönemlerinden biridir. Perinatal dönemde bir takım problemlerin olması bunun başlıca sebeplerindendir (1). Ebeveynlerin sağlıklı bir çocuk sahibi olmayı beklemelerine rağmen, her gebelik sorunsuz bir şekilde devam etmemektedir. Gebeler gebelik süresince bazı problemli süreçler geçirebilmektedir. Bunlardan biri de prenatal girişimsel testlerin gerekli olduğu durumlardır (2). Genetik amniyosentez işlemi kromozomal anomalisi olan fetusları saptamada en sık kullanılan girişimsel tanısal testtir. İlk kez 1956'da (3) elde edilen fetal hücrelerde 'Barr" cisminin varlığı ile fetal cinsiyet tayini için yapılmıştır. Daha sonra 1966 'da (4) amniyon sıvısında fetal karyotip tayini mümkün olmuştur. Bir karyotip anomalisi tespit edildiğinde bu, gebelik terminasyonu ya da sonraki gebelikler için daha uygun bir obstetrik bakım sağlanmasına imkan verir.

Ciddi endişe veya depresyona maruz kalan gebeler psikiyatrik desteğe ihtiyaç duyabilir. Girişimsel tanı yöntemlerinin çoğu bireylere endişe ve korku yaşatmakta, bu durum bireylerde anksiyete ve depresyon kaynaği olabilmektedir (5). Stres durumunun neden olduğu anksiyete ve depresyon, kişilerin fiziksel ve psikolojik durumunu etkileyerek bir tepki oluşmasina neden olabilmektedir. Annenin anksiyete ve depresyon düzeyinin belirlenmesi ile ilgili olarak doğum hekimleri genellikle özel bir dikkat göstermemektedir. Bu dikkat özellikle amniyosentez gibi prenatal tanısal testlerin gerekli olduğu gebelerde çok daha fazla önem taşımaktadır. Antenatal dönemde uygulanan amniyosentezin gebe kadınlarda korku ve anksiyeteye neden olduğunu gösteren çalışmalar mevcuttur (6).

$\mathrm{Bu}$ çalışmanın amacı amniyosentez planlanan gebelerin işlem öncesi anksiyete ve depresyon düzeylerini belirlemek ve bu doğrultuda anksiyete ve depresyonu azaltmaya yönelik girişimlerin gerekliliğini belirlemektir.

\section{GEREÇ ve YÖNTEM}

Çalışma amniyosentez planlanan hastalara amniyosentez öncesinde hastaların anksiyete ve depresyon risk düzeyini saptamak ve elde edilen bulgular doğrultusunda anksiyeteyi azaltmaya yönelik girişimlerin değerini anlamak amacıyla planlanmıştır. Bunun için Necmettin Erbakan Üniversitesi Meram Tıp Fakültesi Kadın Hastalıkları ve 
Doğum Anabilim Dalı Perinatoloji Bilim Dalına Nisan 2016 ile Aralık 2016 tarihleri arasında başvuran ve amniyosentez yapilmasi planlanan ve yapılan 109 gebe dahil edilmiştir. Çalışmaya katılan hastalardan sosyodemografik veri formu ve Hastane Anksiyete Depresyon Ölçeği formlarının doldurulması için bilgilendirilmiş onam alınmıştır.

Amniyosentez endikasyonu için sadece maternal serum tarama testlerinde (birinci ya da ikinci trimester taramasinda) risk tespit edilip, bu nedenle amniyosentez yapılması gereken hastalar çalışmaya alındı. Bunun dışındaki nedenlerle amniyosentez yapılması gereken hastalar ek stresör durumların da sonuçları etkileyebileceği endişesi nedeniyle (mesela fetal anomali tespiti maternal anksiyete ve depresyon düzeyini etkileyebilir) çalışmaya dahil edilmemiştir.

Gebelerin sosyodemografik özellikleri kaydedildikten sonra anksiyete ve depresyon risk düzeyinin belirlenmesi için Hastane Anksiyete Depresyon Ölçeği (HADÖ) kullanıldı. HADÖ (Hospital Anxiety Depression Measure) hastada anksiyete ve depresyon riskini belirlemek ve düzeyinin ölçmek için geliştirilmiştir (5). Ölçeğin Türkiye'de geçerlilik güvenirlik çalışması Aydemir ve arkadaşları (6) tarafından yapılmıştır. HADÖ tanı koymak için kullanılmamaktadır. Anksiyete ve depresyonu kısa sürede tanımak ve risk grubunu belirlemek amacı ile kullanılır. Toplam 14 soru içerir. Bu sorulardan yedisi (tek say1lar) anksiyeteyi ve yedisi de (çift sayılar) depresyonu ölçmektedir. Ölçekte her maddenin puanlaması farklıdır. 1, 3, 5, 6, 8, 10, 11, 13 numaralı sorular 3, 2, 1, 0 biçiminde puanlanır ve giderek azalan şiddeti gösterirler. Geriye kalan 2, 4, 7, 9, 12, 14 numaralı sorular $0,1,2,3$ biçiminde puanlanır. Anksiyete alt ölçeği için 1, 3, 5, 7, 9, 11, 13 numaralı sorulara verilen yanitların puanları toplanırken, depresyon alt ölçeği için $2,4,6,8,10,12$, 14 numaralı sorulara verilen yanitların puanları toplanır. Hastaların her iki alt ölçekten de alabilecekleri en düsük puan 0 iken, en yüksek puan 21'dir. HADÖ'nün Türkçe formunun kesme noktaları anksiyete alt ölçeği için (HADÖ-A) 10, depresyon alt ölçeği (HADÖ-D) için 7'dir.

Verilerin analizinde, sayısal değerler için sayı ve yüzde dağılımı, ortalama, standart sapma, varyans ve non-parametrik veriler için de Kruskal-Wallis testi kullanıldı. Sonuçlar \%95'lik güven aralığında, anlamlılık $\mathrm{p}<0.05$ olarak değerlendirildi.

\section{BULGULAR}

Çalışmaya dahil edilen hastaların demografik verileri tablo 1'de sunulmuştur. Çalışmaya katılan kadınların \%28.4'ü 25-30 yaş aralığında olup \%40.4'ü ilkokul mezunudur (Tablo 1). Gebelerin ortalama amniyosentez yapilma haftaları $18.20 \pm$ 1.90'd1 (aralık: 15-23 hafta).

Çalışmayakatılanhastalarıntamamınınamniyosentez endikasyonu maternal serum tarama testlerinde çıan sonucun cut-off değerin $(1 / 270)$ üzerinde olmasıdır.
Anksiyete düzeylerini etkileyebilecek diğer endikasyonlara bağlı amniyosentez nedenleri (örneğin fetusta aşikar bir anomali tespit edilmiş olması gibi) bu çalışmanın dışında tutuldu.

Tablo 1: Hastaların sosyodemografik verileri.

\begin{tabular}{|l|l|l|}
\hline & Sayı & $\%$ \\
\hline Yaş aralığı & & \\
18- 24 yaş & 25 & 22.9 \\
25- 30 yaş & 31 & 28.4 \\
31- 35 yaş & 26 & 23.9 \\
36 ve üzeri yaş & 27 & 24.8 \\
Toplam & 109 & 100 \\
\hline Öğrenim düzeyi & & \\
Okur-yazar & 7 & 6.4 \\
İlkokul mezunu & 44 & 40.4 \\
Ortaokul mezunu & 15 & 13.8 \\
Lise mezunu & 33 & 30.3 \\
Üniversite mezunu & 10 & 9.2 \\
Toplam & 109 & 100 \\
\hline Meslek & & \\
Çalışmıyor & 46 & 42.2 \\
İşçi & 35 & 26.6 \\
Memur & 26 & 29.4 \\
Kendi işi & 2 & 1.8 \\
Toplam & 109 & 100 \\
\hline Gelir Durumu & 32.1 \\
Gelir giderden az & 22 & \\
Gelir gidere denk & 109 & 100 \\
Gelir giderden fazla & & \\
Toplam & 52.1 \\
\hline
\end{tabular}

Amniyosentez öncesi hastaların anksiyete ölçeği (HADÖ-A) ortalaması $11.18 \pm 2.36$ (aralık: 2-20) olarak bulundu. Kesme noktasi 10 olduğundan hastaların \%72.5'i anksiyete yönünden risk altında bulunmuştur. HADÖ-D ortalaması ise $7.75 \pm 2.19$ (aralık: 2-19) olarak bulundu. Kesme noktası 7 olduğundan gebelerin \%74.2'si depresyon yönünden risk altındadır (Tablo 2).

Katılımcıların yaş, eğitim, meslek ve gelir durumlarına göre HADÖ-A ve HADÖ-D alt ölçek puanları arasında anlamlı bir fark bulunmamıştır.

Tablo 3'de çalışmada kullanılan ölçek olan HADÖ’nün tam metni gösterilmiştir.

Tablo 2: Hastane anksiyete depresyon alt ölçeklerinin ortalamaları.

\begin{tabular}{|c|c|c|c|c|}
\hline & & $\begin{array}{c}\text { Sayı } \\
\text { (Yüzde) }\end{array}$ & $\begin{array}{c}\text { Ortalama } \\
\stackrel{ \pm}{ \pm} \text { Standart Sapma }\end{array}$ & $\begin{array}{l}\text { Minimum } \\
\text { ve } \\
\text { maksimum }\end{array}$ \\
\hline \multirow{2}{*}{ HADÖ- A } & $\begin{array}{c}\text { Eşik altı } \\
\text { ( } \leq 10 \text { puan) }\end{array}$ & $\begin{array}{c}30 \\
(\% 27.5)\end{array}$ & \multirow{2}{*}{$11.18 \pm 2.36$} & \multirow{2}{*}{$2-20$} \\
\hline & $\begin{array}{l}\text { Eşik üstü } \\
\text { (>10 puan) }\end{array}$ & $\begin{array}{c}79 \\
(\% 72.5)\end{array}$ & & \\
\hline \multirow{2}{*}{ HADÖ-D } & $\begin{array}{l}\text { Eşik altı } \\
\text { ( } \leq 7 \text { puan) }\end{array}$ & $\begin{array}{c}28 \\
(\% 25.8)\end{array}$ & \multirow{2}{*}{$7.75 \pm 2.19$} & \multirow{2}{*}{$2-19$} \\
\hline & $\begin{array}{l}\text { Eşik üstü } \\
\text { (>7 puan) }\end{array}$ & $\begin{array}{c}81 \\
(\% 74.2)\end{array}$ & & \\
\hline
\end{tabular}


Tablo 3: Hastane anksiyete ve depresyon ölçeği.

Hastane anksiyete ve depresyon ölçeği.

1. Kendimi gergin "paylayacak gibi" hissediyorum.

(3) Çoğu zaman (2) Birçok zaman (1) Zaman zaman, bazen (0) Hiçbir zaman

2. Eskiden zevk aldığım şeylerden hala zevk alıyorum.

(0) Aynı eskisi kadar (1) Pek eskisi kadar değil (2) Yalnızca biraz eskisi kadar (3) Neredeyse hiç eskisi kadar değil

3. Sanki kötü bir şeyler olacakmış gibi korkuya kapılıyorum.

(3) Kesinlikle öyle ve oldukça şiddetli (2) Evet, ama çok şiddetli değil (1) Biraz, ama beni endişelendirmiyor (0) Hayır, hiç öyle değil

4. Gülebiliyorum ve olayların komik taraflarını görebiliyorum.

(0) Her zaman olduğu kadar (1) Şimdi pek o kadar değil (2) Şimdi kesinlikle o kadar değil (3) Arttk hiç değil

5. Aklımdan endişe verici düşünceler geçiyor.

(3) Çoğu zaman (2) Birçok zaman (1) Zaman zaman, ama çok sık değil (0) Yalnızca bazen

6. Kendimi endişeli hissediyorum.

(3) Hiçbir zaman (2) Sık değil (1) Bazen (0) Çoğu zaman

7. Rahat rahat oturabiliyorum ve kendimi gevşek hissediyorum

(0) Kesinlikle (1) Genellikle (2) Sık değil (3) Hiçbir zaman

8. Kendimi sanki durgunlaşmış gibi hissediyorum.

(3) Hemen hemen her zaman (2) Çok sık (1) Bazen (0) Hiçbir zaman

9. Sanki içim pır pır ediyormuş gibi tedirginliğe kapılıyorum.

(0) Hiçbir zaman (1) Bazen (2) Oldukça sık (3) Çok sık

10. Dış görünüşüme ilgimi kaybettim.

(3) Kesinlikle (2) Gerektiği kadar özen göstermiyorum (1) Pek o kadar özen göstermiyorum (0) Her zamanki kadar özen gösteriyorum

11. Kendimi sanki hep bir şey yapmak zorundaymışım gibi huzursuz hissediyorum.

(3) Gerçektende çok fazla (2) Oldukça fazla (1) Çok fazla (0) Hiç değil

12. Olacakları zevkle bekliyorum.

(0) Her zaman olduğu kadar (1) Her zamankinden biraz daha az (2) Her zamankinden kesinlikle daha az (3) Hemen hemen hiç

13. Aniden panik duygusuna kapılıyorum

(3) Gerçektende çok sık (2) Oldukça sık (1) Çok sık değil (0) Hiçbir zaman

14. İyi bir kitap, televizyon yada radyo programından zevk alabiliyorum.

(0) Sıklıkla (1) Bazen (2) Pek sık değil (3) Çok seyrek

\section{TARTIŞMA}

Amniyosentez en yaygın uygulanan prenatal girişimsel işlem olmasına karşın psikolojik etkileri çok az dikkate alınmıştır. Özellikle işlem öncesinde ve sırasında oluşan stres çoğunlukla göz ardı edilir. Çalışmamızda amniyosentez öncesi gebelerin HADÖ-A puan ortalamas1 $11.18 \pm 2.36$ ve HADÖ-D puan ortalaması $7.75 \pm 2.19$ olarak bulunmuştur. Yapılan bir çalışmada HADÖ-A puan ortalaması 4.80 ve HADÖ-D puan ortalamas1 4.00 olarak bulunmuş ve çalışmamızda bulduğumuz değerlerden daha düşük olduğu görülmektedir (9). Diğer bir çalışmada ise işlem öncesi HADÖ-A puan ortalaması 6.60 olarak saptanmışırı (10).

Bir durumun stresli olarak algılanmas1, durumun yapısına ve kişinin bu durumla baş etme ve savunma mekanizmalarına bağlıdır. Anksiyete, kişiyi yaklaşan tehlikeye karşı uyarır ve kişinin bu durumla baş etmek üzere önlem almasını sağlamaktadır (11). Bu yüzden bu çalışmada, gebenin mevcut gebeliğini kaybetme ve işlem sonucunun olumsuz çıkmas1 gibi durumlar ile baş edebilmeleri için savunma mekanizması olarak anksiyetelerinin yüksek çıktığı düşünülmektedir.

Amniyosentez işleminde en çok anksiyete yaratan durumlar işlem sırasında fetüsün zarar görmesi ihtimali, gebeliğin kaybedilmesi riski ve sonucun patolojik çıkma ihtimalidir (12). Çalışmamızda amniyosentez öncesi HADÖ puan ortalamaları yüksek çıkan gebelerin yaş, eğitim durumu ve gelir düzeyleri ayrı ayrı incelendiğinde bu alt gruplar arasında anlamlı bir ilişki olduğu görülmemiştir. 
Çalışan kadınlar eğitimleri için ayırdıkları süreden ötürü ileri yaşta gebelik yaşamaktadırlar. Bağlantılı olarak da maternal kan tarama testi sonuçları bu yaş grubunda riskli çıkmaktadır (13). Başka bir çalışmada da gebelerin sosyo-demografik özellikleri ile anksiyete depresyon düzeyleri arasında anlamlı bir fark bulunmamıştır (14).

Anksiyete ve depresyon düzeylerinin işlemden hemen önce bilgilendirilen gebelerde daha yüksek olduğu da iddia edilmiştir (5). Diğer bir çalışmada da işlem öncesi hastaların anksiyetli oldukları ve işlemden hemen sonra da bu anksiyete düzeylerinin arttığ1 vurgulanmıştır (15). Bizim çalışmamızda HADÖ işlemden önce verilen danışmanlığı takiben yapılmış ve çalışmaya dahil edilen grupta hem anksiyete ve hem de depresyon düzeyleri anlamlı şekilde yüksek bulunmuştur.

Çalışmamızda HADÖ puanları yüksek çıkan gebelerin özellikle bir grubuna yoğunlaşmamış, yaş, gelir düzeyi ve eğitim durumu ile ilişkisi ayrı ayrı irdelendiğinde herhangi bir ilişkisi olmadığı görülmüştür.

Sonuç olarak gebelik ve doğum sonrası dönem kadın yaşamında psiko-medikal açıdan özel bir yer tutmaktadır. Bu dönemde endişe ve korku oluşturacak amniyosentez gibi işlemlerin risk grubundaki hastalarda psikiyatrik destek gerektirecek boyuta ulaşabileceği unutulmamalıdır. Bu risk grubundaki gebelerin belirlenmesi ve verilecek destek ile kad1nın yaşam kalitesi yükseltilebilir. Amniyosentezin anne adayında yaşatacağı endişe ve korku, anksiyete ve depresyon kaynağı olabilir ve meyilli kadınlarda klinik semptomların oluşmasına yol açabilir. Bunun ile ilgili olarak obstetrisyenlerin dikkatli olması ve gerektiğinde psikiyatrik destek için hastalar1 yönlendirmeleri uygun olabilir.

\section{KA Y N A KL A R}

1. Verreault $N$, Da Costa D, Marchand A, Ireland K, Dritsa M, Khalifé S. Rates and risk factors associated with depressive symptoms during pregnancy and with postpartum onset. J Psychosom Obstet Gynaecol 2014; 35:84-91.

2. Sanhal CY, Mendilcioglu I, Ozekinci M, Simsek M, Bozkurt S. Comparison of pre-procedural anxiety and depression scores for patients undergoing chorion villus sampling and amniocentesis: An alternative perspective on prenatal invasive techniques. Pak J Med Sci 2015; 31:1038-1042.

3. Fuchs F, Rus P. Antenatal sex determination. Nature 1956; 177:330.

4. Steele MW, Breg WR Jr. Chromosome analysis of human amniotic-fluid cells. Lancet 19; 1:383-385.

5. Balci O, Acar A, Mahmoud AS, Colakoglu MC. Effect of Pre-Amniocentesis Counseling on Maternal Pain and Anxiety. J Obstet Gynaecol Res 2011; 37:1828-1832.

6. Sevgül Dönmez, Hande Dağ, Mert Kazand. Amniyosentez Öncesi Gebelerde Anksiyete ve Depresyon Risk Düzeylerinin Belirlenmesi. Acıbadem Universitesi Sağlık Bilimleri Dergisi 2012; 3:255-261.

7. Zigmond AS, Snaith RP. The hospital anxiety and depression scale. Acta Psychiatr Scand 1983; 67:361-370.

8. Aydemir Ö, Güvenir T, Küey L, Kültür S. Hastane Anksiyete ve Depresyon Ölçeği Türkçe Formunun Geçerlik Güvenirlik Calışmast. Türk Psikiyatri Dergisi 1997; 8:280-287.

9. Cederholm M, Axelsson O, Sjödén PO. Psychological Distress Before and After Prenatal Invasive Karyotyping. Acta Obstet Gynecol Scand 2001; 80:539-545.

10. Suntornlimsiri W, Naunkeaw K. Clinical Correlates of Pain with Second-Trimester Genetic Amniocentesis. J Med Assoc Thai 2009; 92:15671572.

11. Romeo RD, Mueller A, Sisti HM, Ogawa S, McEwen BS, Brake WG Anxiety and fear behaviors in adult male and female C57BL/6 mice are modulated by maternal separation. Horm Behav 2003; 43:561-267.

12. Ruhi H, Yürür NK, Tükün A, Bökesoy I. The Role of Genetic Counseling on Decisions of Pregnant Women Aged 35 Years or Over Regarding Amniocentesis in Turkey. Europan Journal of Medical Genetics 2004; ding Amnioc.

13. Ng CCM, Lai FM, Yeo GSH. Assessment of Maternal Anxiety Levels Before and After Amniocentesis. Singapore Med J 2004; 45:370-374.

14. Milić BB, Dorčić TM, Kuljanić K, Petrović O. Stress and Anxiety in Relation to Amniocentesis: Do Women Who Perceive Their Partners To Be More Involved in Pregnancy Feel Less Stressed and Anxious? Croat Med J 2010; $51: 137-143$

15. Tercyak KP, Johnson SB, Roberts SF, Cruz AC. Psychological Response to Prenatal Genetic Counceling and Amniocentesis. Patient Education and Counseling 2001; 43:73-84. 